\title{
Anemia among Pregnant Women at Nepalgunj Medical College
}

\author{
$B C D$
}

\begin{abstract}
Introduction: Anemia in pregnancy is major health issue of developing countries responsible for adverse maternal and fetal outcome. According to World health organization pregnant women with hemoglobin level less than $11 \mathrm{gm} / \mathrm{dl}$ in first trimester and less than $10.5 \mathrm{gm} / \mathrm{dl}$ in second and third trimester are considered to be anemic. Iron deficiency anemia is common during pregnancy followed by megaloblastic anemia. Aims: To find out the prevalence of anemia during pregnancy. To correlate the maternal and fetal complications associated with anemia during pregnancy. Methods: This is a prospective hospital based study done at department of obstetrics and gynecology Nepalgunj Medical College from July 2020 to January 2021. All pregnant women with hemoglobin level $<11 \mathrm{gm} / \mathrm{dl}$ were enrolled in the study. Data were collected from antenatal clinic and biochemistry laboratory. Results: In this study maximum participants were of age group $20-25$ consisting of $38.5 \%$. Anemia was more common in multiparous i.e. $60 \%$ as compared to primipara i.e. $40 \%$. In this study maximum participant had vaginal delivery (57\%) followed by LSCS $(29 \%)$ then instrumental delivery (14\%). These ladies had complications like postpartum hemorrhage $(27.7 \%)$, preterm labor (16.9\%), pregnancy induced hypertension (9.2\%). similarly $10.8 \%$ had sepsis and $20 \%$ had no complications. About $23.1 \%$ babies delivered by anemic ladies required neonatal intensive care. Intrauterine growth restriction was seen in $12.3 \%$, preterm birth in $10.3 \%$ and $53.8 \%$ babies had no complications. Conclusion: The prevalence of anemia during pregnancy is high leading to adverse maternal and fetal outcome.
\end{abstract}

Keywords: Anemia, Fetal outcome, Maternal outcome, Prevalence

Author:

1. Dr. Durga BC

Address for Correspondence:

Dr. Durga BC

Assistant professor

Department of Obstetrics and Gynecology

Nepalgunj Medical College and Teaching Hospital

Kohalpur, Banke

E-mail: durgabc53@gmail.com

\section{INTRODUCTION}

Anemia in pregnancy is a major health issue of developing country, responsible for adverse maternal and fetal outcome. It is decrease amount of red blood cell or hemoglobin $(\mathrm{Hb})$ concentration with decrease oxygen carrying capacity of blood during pregnancy. ${ }^{1,2}$ According to WHO pregnant woman with hemoglobin level less than $11 \mathrm{gm} / \mathrm{dl}$ in first trimester and less than $10.5 \mathrm{gm} / \mathrm{dl}$ in second and third trimester are considered anemic and divided in to mild anemia ( $\mathrm{Hb} 9$ to $10.0 \mathrm{gm} /$ dl) moderate anemia ( $\mathrm{Hb} 7$ to $8.9 \mathrm{gm} / \mathrm{dl}$ ) severe anemia hemoglobin less than $7 \mathrm{gm} / \mathrm{dl}^{3}{ }^{3}$ The most common cause of anemia during pregnancy is iron deficiency anemia, other causes like folate, vitamin B12 deficiency; congenital anemia (Sickle anemia, Thalassemia) may worsen during pregnancy due to increase demands.

Hemolytic anemia, aplastic anemia and hematologic malignancies are less common cause of anemia during pregnancy. ${ }^{4}$ There is a risk of intra uterine fetal death, preterm labor, neuro developmental damage to fetus and risk of heart failure, eclampsia, pre-eclampsia post-partum hemorrhage, maternal mortality, risk of blood transfusion and operative delivery. ${ }^{5}$ Anemia in pregnancy is common in this region also hence the study was carried out to evaluate the prevalence, types and severity of anemia and to correlate the association between the anemia and maternal and fetal complications.

\section{METHODS}

This was a prospective hospital based study done at Department of Obstetrics and Gynecology Nepalgunj Medical College. Data were collected from July 2020 to January 2021. Ethical clearance was taken from institutional review committee. All pregnant women who attended antenatal clinic with hemoglobin level less than $11 \mathrm{gm} / \mathrm{dl}$ were enrolled in the study. The pregnant ladies with chronic illness were excluded from the study. The informed and verbal consent was taken; data were collected on the basis of age group, types of anemia, maternal complications and fetal complications. Data were recorded in standard Performa and analyzed by using version 17 of SPSS.

\section{RESULTS}

During the study period 2500 pregnant ladies visited antenatal 
clinic out of them 65 pregnant had anemia making the prevalence of $26 \%$. The maximum number of patients was in between 20-25years. The overall mean age was 23.89 \pm 4.27 (Table I). Majority had iron deficiency anemia i.e. 40 patients $(61.5 \%)$ out of 65 , followed by megaloblastic anemia. When the severity was analyzed, 27 (29.2\%) women had mild anemia (Table II).

When the association between the maternal complications and hemoglobin level was analyzed, it was found that anemia during pregnancy was directly related to the maternal complications $(p=0.003)$. Many patients had postpartum hemorrhage followed by preterm labor (Table III).

Inspite having some severity of anemia, 57\% had spontaneous vaginal delivery, $14 \%$ had instrumental delivery and $29 \%$ had cesarean section (Fig 1).

Babies of anemic mother had complications like, IUGR seen in $12.3 \%$, preterm birth in $10.3 \%$ and need for intensive care in 23.1\% (Table IV).

\begin{tabular}{|ccc|}
\hline Age group & Frequency & Percentage (\%) \\
\hline$<20$ & 4 & 6.2 \\
\hline $20-25$ & 25 & 38.5 \\
\hline $25-30$ & 21 & 32.5 \\
\hline$>30$ & 15 & 23.1 \\
\hline Total & 65 & 100 \\
\hline
\end{tabular}

Table I: Distribution of patients according to the age group

\begin{tabular}{|ccccc|}
\hline Types of anemia & $\begin{array}{c}\text { HB Level } \\
\text { (severe) }\end{array}$ & $\begin{array}{c}7-8.9 \\
\text { (moderate) }\end{array}$ & $\begin{array}{c}\text { 9-10.9 } \\
\text { (mild) }\end{array}$ & \\
\hline $\begin{array}{c}\text { Iron deficiency } \\
\text { anemia }\end{array}$ & 10 & 13 & 17 & 40 \\
\hline $\begin{array}{c}\text { Megaloblastic } \\
\text { anemia }\end{array}$ & 5 & 3 & 6 & 14 \\
\hline $\begin{array}{c}\text { Sickle cell anemia } \\
\text { Hemolytic anemia }\end{array}$ & 2 & 2 & 3 & 7 \\
\hline Total & 19 & 19 & 27 & 65 \\
\hline
\end{tabular}

Table II: Severity of anemia and hemoglobin level

\begin{tabular}{|ccccc|c|}
$\begin{array}{c}\text { Maternal } \\
\text { complication }\end{array}$ & $\begin{array}{c}\text { HB Level } \\
\text { Severe) }\end{array}$ & $\begin{array}{c}7-8.9 \\
\text { (Moderate) }\end{array}$ & $\begin{array}{c}\text { 9-10.9 } \\
\text { (Mild) }\end{array}$ & Total & $\begin{array}{c}p \\
\text { Value }\end{array}$ \\
\hline PIH & 0 & 3 & 3 & 6 & \\
\hline PPH & 3 & 6 & 9 & 18 & \\
\hline $\begin{array}{c}\text { Preterm labor } \\
\text { Blood }\end{array}$ & 4 & 5 & 2 & 11 & \\
$\begin{array}{c}\text { transfusion } \\
\text { Sepsis }\end{array}$ & 3 & 1 & 1 & 10 & \\
\hline None & 1 & 2 & 2 & 7 & \\
\hline Total & 19 & 19 & 27 & 65 & \\
\hline
\end{tabular}

Table III: Correlation between maternal complication and hemoglobin level

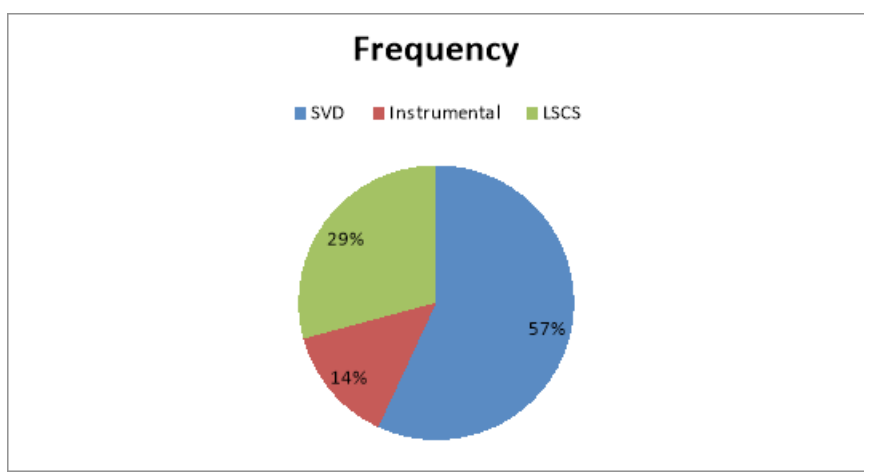

Figure 1: Distribution according to mode of delivery

\begin{tabular}{|lcc|}
\hline \multicolumn{1}{|c}{ Complications } & Frequency & Percentage \\
\hline None & 35 & 53.8 \\
\hline NICU admission & 15 & 23.1 \\
\hline IUGR & 8 & 12.3 \\
\hline Preterm birth & 7 & 10.3 \\
\hline Total & 65 & 100 \\
& Table IV: Fetal complications & \\
\hline
\end{tabular}

\section{DISCUSSION}

In this study the overall prevalence of anemia among pregnant woman was $26 \%$. The overall incidence was $41.02 \%$ in the study conducted by Singh P et al ${ }^{1}$ and $41.2 \%$ in the study conducted by Meleko $A .{ }^{13}$ In our study maximum participants were of age group (20-25) year's i.e.38.5\% which is similar to the study conducted by Meleko A. ${ }^{13}$ In the study conducted by Bansal $\mathrm{R}$ et al. ${ }^{14}$ maximum participants were more than 25 years of age i.e. (68.3\%). In our study most of the participants were multiparous (60\%) which is similar to the study conducted by Rachel $A .^{2}$ and Nair Met al. ${ }^{7}$ According to the study conducted by Meleko A. ${ }^{13} 52.9 \%$ participants were primipara and $46.1 \%$ were multipara. In our study $56.9 \%$ patient had spontaneous vaginal delivery, $13.8 \%$ had instrumental delivery and $29.22 \%$ had cesarean section which is similar to the study done by Nair $\mathrm{M}$ and et $\mathrm{al}^{7}$ and Diejomaoh F.M.E. ${ }^{11}$ In our study maximum participants had iron deficiency anemia i.e. $61.5 \%$ followed by megaloblastic anemia i.e. $21.5 \%$ which is similar to the 
study conducted by Diejomaoh F.M.E. ${ }^{11}$ where the incidence of iron deficiency anemia was $58 \%$. In our study $27.7 \%$ had post-partum hemorrhage (PPH), $16.9 \%$ had preterm labor. The study conducted by Maskey M. ${ }^{3} \mathrm{PPH}$ was seen in $92.9 \%$ and $1 \%$ had preterm labor. In the study conducted by Patra S. ${ }^{12} 57 \%$ of babies required NICU admission, $90 \%$ had preterm birth, $30 \%$ were low birth weight/ intrauterine growth restriction (IUGR). In our study $23.1 \%$ had NICU admission only $10.3 \%$ had preterm birth and $12.3 \%$ babies had IUGR.

\section{LIMITATIONS}

Limitations of this study are small sample size and short duration of study. Because of the diversified cultural practices food habits in different ethnic groups cause and prevalence of anemia during pregnancy is different so studies should be done separately for different ethnic groups.

\section{CONCLUSION}

Anemia during pregnancy is responsible cause for adverse fetomaternal outcome like postpartum hemorrhage ,pregnancy induced hypertension, preterm labor in mother and risk of preterm birth ,NICU admission, IUGR ,Low birth weight in newborn. Hemoglobin level below $10.5 \mathrm{gm} / \mathrm{dl}$ in any trimester should be screened to rule out cause of anemia. During pregnancy proper diagnosis and treatment of anemia is required to prevent complication.

\section{REFERENCES}

1. Meleko A.Prevalence of anaemia and its associated factors. Health science J. 2017; 11(5):1-8.

2. Vanamala V.G.,Rachel A,Pakyanadhan S. Incidence of anaemia in pregnant women .Int .J Reprod Contracept Obstet Gynaecol.2018;7(2):462-66.

3. Frayne J,PinchoD. Anaemia in pregnancy. AJGP.2019;48(3):125-29.

4. F.M.E. Diejomao. Anemia in Pregnancy. Int J Gynaecol and Obstet.1999; 65:299-301.

5. Bansal R. Prevalence and factors associated with anemia. Adesh university J of med sci. 2020;2(1):42-48.

6. D.Geelhood et al Maternal and Fetal Outcome after Severe Anemia in Pregnancy. Acta obstetricia Gynaecologica. 2006; 85:49-55.

7. Horowitz. Anaemia in pregnancy. Clin Lab Med. 2013;33:28191.

8. Nair M. Association between maternal anemia and pregnancy outcome. BMJ Global Health. 2016;1(26):201526.

9. Bencaiova G, Burehardt T, Breymann C. Anaemia prevalence and risk factors in pregnancy. European J of Int. Med. 2012;23:529-33.

10. Levy A. Maternal anaemia during pregnancy is an independent for LBW and preterm delivery. European J Obstet and Gynaecol.2005; 12:182-86.

11. Reddy R, SCK R, Pambi S. Study of prevalence of anaemia among pregnant women. Int $\mathrm{J}$ of Contemporary medical Research. 2016;3(8):2388-91.

12. Patra S, Pasrija S, Trivedi SS, Puri M. Maternal and Perinatal outcome with severe anaemia in pregnancy. Int J Obstet and Gynaecol. 2005;91:164-65. 